\title{
Fiscal and financial conditions for a stronger euro area
}

\author{
Vítor Constâncio \\ Lisbon School of Economics and Management, University of Lisbon, Portugal
}

\begin{abstract}
The euro is irreversible but it needs reform to address well-known design deficiencies and also new challenges. Although progress has been made, further steps are needed, the most important of which are: revision of the fiscal rules, establishing a central stabilisation capacity, and completing the banking union (especially a deposit insurance, a capital market union based around a common safe asset, and improved macroprudential policy). This article sets out the necessary reforms in these areas in detail.
\end{abstract}

Keywords: EMU reform, fiscal rules, Stability and Growth Pact, European safe asset

JEL codes: E02, E50, E60, O52

\section{INTRODUCTION}

I thank the organisers for inviting me to participate in this topical conference and in a session dedicated to discussing 'The euro at 30? Institutional challenges'. Let me start by eliminating the interrogation from this title: I think the euro is irreversible and will be around for longer than ten years from now. This does not mean it does not require further changes to its institutional framework, both to improve economic performance and to dispel thoughts of redenomination risk and populist backlash. Europe needs a robust, unassailable, growing euro area (EA).

Some of the reforms needed to achieve that are part of the logical completion of what a monetary union should have been from the start; others stem from the new challenges and risks that Europe now faces. Among the risks facing Europe are those it shares with all other advanced economies: the low-growth, low-inflation regime and the emergent forces of populism and nationalism embedded in a new geopolitical situation that threatens the fragmentation of the world economic system, as illustrated by ongoing trade and currency disputes. The new geopolitical context is particularly challenging for Europe, squeezed between the shattering of multilateralism by a gradually more hostile US, an aggressive and destabilising Russia and the economic expansionism of China. The new context nudges Europe into becoming a player in the international power game.

One can doubt that there will be sufficient unity of interest and purpose among European countries for this fundamental change to easily occur. However the economic dimensions of the new context will impact economic strategies. It is, for instance, doubtful that Europe can continue to grow like an export-driven economy with persistent huge current-account surpluses that generate international reactions. Other European specific risks stem from the ongoing demographic decline in significant parts of the continent and from the persistent bias introduced by the prevailing pro-cyclical macroeconomic policy regime that hinders

Received 4 May 2020, accepted 27 May 2020 
the full development of Europe's economic growth potential. To these risks we can add that the EA has not yet completed the set of reforms necessary to overcome the shortcomings of its initial deficient design.

In spite of all the important institutional reforms introduced since 2010 that put a stop to existential crises, it is easy to see that monetary union is still incomplete. The main shortcomings are in the fields of macroeconomic management and financial stability policies. The recent controversial decision by the German Constitutional Court about the legality of the European Central Bank (ECB) securities market purchases opened a dangerous legal debate that was considered settled by the European Court of Justice in 2018. Besides the the need to solve this issue once and for all, the list of necessary reforms to make it robust and significantly reduce redenomination risk is easy to infer from what I just mentioned:

1. Correction of the pro-cyclical fiscal policy bias at the EA level via the revision of the Stability and Growth Pact (SGP); the better coordination of national fiscal policies to build up a European fiscal stance; the creation of a European Stabilisation Fund with temporary transfers linked to significant unemployment fluctuations.

2. Completion of Banking Union with the European Deposit Insurance Scheme (EDIS) and the financial backstop to the European Resolution Fund.

3. Creation of a Capital Markets Union, including the introduction of a European safe asset, which is essential also for other goals.

4. Strengthening of macroprudential policy by expanding ECB powers, enlarging the set of macroprudential instruments covered by the capital requirements directives (for example, to include borrower-based measures), and streamlining of approval procedures.

Among all these points, my absolute priorities are the creation of a European Stabilisation Fund, the revision of the SGP, and the issuance of a European safe asset. It is essential to correct the pro-cyclical bias of fiscal policy that has hampered economic adjustment while providing some central stabilisation. A more robust banking sector would benefit by reducing its degree of concentration on domestic sovereign bonds by diversifying towards a European safe asset that is also a crucial component of the capital markets union and the international role of the euro.

\section{THE NEW ROLE OF FISCAL POLICY IN MACROECONOMIC STABILISATION}

Concerning fiscal policy, the pro-cyclical bias can be illustrated by comparing, from 2000 to 2018, the evolution of the output gap and the cyclical adjusted primary budget balance.

In contrast to fiscal policy in the US, in the EA a restrictive policy was implemented after 2011, with the structural primary balance becoming positive, while the output gap stayed negative. The double dip in growth in the EA was mostly due to the coordinated fiscal consolidation among EA country members implemented from 2011 to 2013. Simulations with the European Union (EU) Commission model Quest show that fiscal policy contributed to cumulative GDP deviations from the baseline scenario that vary by country from 8 to 18 per cent, including spillover effects varying from 1 to 2 per cent (in't Veld 2013; see also Rannenberg et al. 2015). Fatás/Summers (2015) illustrate how excessive consolidation leaves behind permanent effects via hysteresis and can be self-defeating, even aggravating the public-debt ratio in some cases. Fatás (2018) also illustrates how the GDP impact of fiscal consolidation leads to a downward revision of potential output and therefore to a justification for more fiscal restraint in what he calls 'a fiscal doom loop'. 
These outcomes already indicate existing problems with the SGP. In general fiscal rules are necessary to counter the 'deficit bias' that may have many causes, from electoral competition to informational problems or to time inconsistency (see Calmfors/Wren-Lewis 2011). However, in a monetary union there are additional reasons for the existence of such rules, either to avoid countries' free-riding or to control undesirable externalities. They refer both to the spillovers from possible debt restructuring in a member country and to demand externalities from fiscal policy.

A good fiscal rule should take these externalities into account and cater for two main goals: (i) control 'deficit bias' to avoid excess debt accumulation; and (ii) allow public finance to play a macroeconomic stabilisation role as a shock absorber, which is particularly important for countries in a monetary union that have lost their own monetary policy.

However, the Keynesian use of fiscal policy was pushed back by mainstream economics over decades with reference to all sorts of arguments, from alleged unavoidable crowdingout to unrealistic Ricardian equivalence. The reduction of the fiscal policy stabilisation role attained its culmination with the appearance of so-called New Keynesian models that assumed total efficiency of monetary policy to maintain the economy at its economic potential and targeted inflation, just by changing interest rates.

In practice, we know that monetary policy does not have the divine powers that these models pretend. However, their dominance consolidated a mainstream consensus that monetary policy was the sole policy to deal with output and employment stabilisation, reserving fiscal policy mainly for microeconomic goals and an overall control of public debt. The only admitted exception to this division of labour applies when monetary policy is significantly restricted. This is obviously the case for a member of a monetary union that, having shared monetary sovereignty, has to use fiscal policy for stabilisation purposes. It is also the case when monetary policy has almost exhausted its tools.

In my view, the present European rules, institutions and policies do not appropriately recognise these two important points. First, the fiscal rules - the SGP - are unbalanced in not allowing sufficient room for the stabilisation role of fiscal policy, making it pro-cyclical at the euro area level as I mentioned before. Second, there is not sufficient recognition that monetary policy is constrained in its effectiveness, not only in the short term (when we face the risk of a significant slowdown) but also in the medium term (as a consequence of the secular stagnation that is affecting advanced economies). I will deal now with these two problems, implying that there is in Europe an urgent need for a fundamental rethinking of the role of fiscal policy.

The first problem refers to the limitations of monetary policy in an environment of low inflation and interest rates already at zero or negative levels. Quantitative easing (QE), acting directly over medium-term rates, was valuable to address the crisis in 2008 and continues to have some effectiveness. Attempts to explore the exchange-rate channel could only lead to currency wars that are destructive and self-defeating. Bringing down still further negative rates should be rejected given the detrimental effects on financial institutions and financial stability.

The highly negative rates would also trigger asset-price bubbles, zombie firms' survival (lowering productivity), and pressure on pension schemes that could lead to increased savings for old age, frustrating the expected increase in demand. To these aspects we could also add the political economy consequences of the banks starting at a certain point to apply negative rates to retail deposits.

All these points question the conventional belief that monetary policy can do everything, and that fiscal policy should be passive. Unfortunately, Milton Friedman and monetarism convinced many people that central banks can put inflation at whatever level they please because inflation is always a monetary phenomenon. Evidence has overwhelmingly disproved that myth. Before the excesses of monetarism, theory and indeed historical evidence 
consistently showed that monetary policy is very efficient in controlling high inflation but always has limitations in confronting depressed economies and very low inflation.

This reality led Ben Bernanke in 2003 to advocate a type of 'helicopter money' for Japan (Bernanke 2003), with temporary monetary financing of public expenditures. In August 2019, well-known former central bankers formalised this approach by proposing the creation by Treasuries of emergency packages of expenditures, ready to be implemented, leaving central banks to decide the timing and amounts to be implemented (Bartsch et al. 2019).

These proposals, put forward by such mainstream policymakers, reflect an acute awareness of the present monetary policy limits and the need for fundamental new thinking about macroeconomic policy, Naturally, to be applied in the euro area, these monetary financing proposals would require a quite unlikely Treaty change. Another version of 'helicopter money' refers to central-bank direct distribution of money to every citizen, an impractical proposal to implement. In the US there are also discussions of a more expansionary fiscal policy around the ideas of the flawed modern monetary theory (MMT). Europe is far away from all such debates. With present thinking, when the next recession comes, we should know that monetary policy lacks the tools to confront it alone and stimulate growth. If fiscal policy does not respond in a significant way, the euro area may face a new crisis, potentially with deep political consequences.

The second problem with monetary policy is more structural and is connected with the fact that advanced economies are stuck in a protracted phase of secular stagnation with low growth, low inflation and low interest rates. Its main feature is the unbalance between the high propensity to save versus lower prospects for investment. Secular stagnation in this case refers to the demand-side version promoted by Larry Summers (see Summers 2016), which implies a situation of persistent lack of demand. The real equilibrium interest rate that ensures the planned savings-investment balance at full employment may indeed become negative, as recent estimates for the advanced economies indicate.

There are several structural causes for that imbalance between planned savings and investment, reflecting lack of aggregate demand: demographic developments, technological shifts towards lower priced investments, income inequality, risk aversion and consequent increase in risk premia.

While these create obstacles for the economy to reach potential, there are also supplyside structural factors, underlined by Robert Gordon in a series of papers (see Gordon 2016), which contribute to the low growth of potential output itself. The two broad frameworks about secular stagnation are therefore not mutually exclusive. One emphasises supply-side factors that lower potential growth while the other points to chronic weakness in demand as the root cause of secular stagnation. The fact that prices show low upward dynamics indicates that lack of demand factors prevail.

What is relevant here is that secular stagnation undermines the role of monetary policy as it cannot, or should not, continuously embark into ever-deeper negative rates. This implies that fiscal policy must play a more active role. To deny this does not make any economic sense. If the private sector wants to save more than spend on real investment, three things happen. First, there is a current-account surplus, and the corresponding investment abroad may have lower returns than domestic investment. Second, interest rates move lower while asset prices, including property prices, tend to rise. Thirdly, the State can go into deficit, dissaving to offset private 'excess' saving. In such a situation, the State should expand its deficit and increase its investments as well as the supply of government bonds. This would also lead to higher interest rates and a lower current-account surplus. Germany in particular, with its high external surplus, should carefully ponder this. But the euro area as a whole has maintained over the years a surplus well above the Chinese one. A fiscal stimulus would thus solve several problems at once. The very large current-account surplus also leads to hostile reactions from 
other countries, especially from the United States. This entails the danger of retaliation against Europe as a whole and Germany in particular.

Fortunately, the very low interest rates, which secular stagnation says will continue in the foreseeable future, generate additional fiscal space. Olivier Blanchard (2019), in his AEA lecture, highlighted how the very low rates contribute to mitigating or even eliminating the consequences of budget deficits on both the debt-to-GDP ratio and the welfare costs of higher public debt. This is the result of the average risk-free rate paid by sovereign debt being below the rate of GDP growth. This has happened mostly in recent decades in the US, albeit less so in other advanced countries. Since the 1960s, that relationship prevailed nevertheless 50 per cent of the time in OECD countries. Financial markets seem to agree, judging by the embedded expectations of low rates for up to 30 years! On the other hand, if inflation would increase in the future or countries would embark on high primary budget deficits, we could have a sudden upward revision of yields, changing their relationship with the growth rate. This means that very high debt ratios, some above 100 per cent, haven't ceased to be a problem all of a sudden. However, the prospect of a prolonged period of low rates does provide some easing of concerns with the debt, especially when fiscal policy is called upon to perform a stronger role in our economies.

\section{THE STABILITY AND GROWTH PACT REVISION}

In view of these new perspectives, we need in Europe to undergo a conceptual change and promote the revision of our pro-cyclical fiscal framework. For a lasting resilience of the euro area, we must have a better way of dealing with cyclical adjustment in our economies. The time has arrived to start discussing the revision of the SGP to achieve a better balance between its two objectives of controlling the debt externality among member countries and allowing a proper stabilisation role for fiscal policy. Both goals are important in a monetary union.

A fiscal rule can be designed around norms for the debt, the deficit or the expenditure path. Not to be undone, the present European rule uses all three, ${ }^{1}$ in a maze of rigid quantitative targets but also exceptions that requires a 'Vade Mecum' with more than 200 pages to be explained. It is too complex and difficult to manage and enforce, as it is open to contradictory interpretations. Also, the rules became more intrusive, creating the potential for political tensions. The European Fiscal Board assessed that the Pact has 'overlapping fiscal requirements that occasionally offer conflicting signals: a structural adjustment and a target for debt reduction' and 'policies are monitored using a multitude of indicators, which inevitably cause conflicting signals' (European Fiscal Board 2019a: 131). Sometimes, these conflicts make impossible the full use of the automatic stabilisers.

During the crisis, in 2009, Germany exchanged its 1969 law, which instituted the 'golden rule' allowing deficits equal to investment expenditure, with a new law establishing that the maximum structural deficit is 0.35 per cent and any past deviations accumulate in a 'memory account' to be wound down in the future. ${ }^{2}$ Following this path, albeit in a slightly softer way, the SGP regulations were significantly tightened in 2011 and in 2012 when

1. Countries are subject to quantitative targets for the debt, for two concepts of deficit (one nominal, another structural), for expenditure growth, and for annual targets regarding the degree of progress towards the debt target and the admissable medium-term structural deficit.

2 . The 'debt brake' law was adopted in 2009, revoking the 'golden rule' in place since 1969. See Thiele (2015). 
25 EU countries signed an Intergovernmental Treaty, ${ }^{3}$ the so-called Fiscal Compact, introducing stricter rules regarding deficits and debt. A maximum medium-term objective for the structural deficit was set at 0.5 per cent, which, if we assume that over the very long term, positive and negative output gap effects cancel out, implies a long-term debt ratio of around 15 per cent if nominal average growth varies between 3 and 4 per cent.

Another change was the imposition that any deviation above the 60 per cent target has to be reduced by 5 per cent per year on average over three years. Besides being the average level of the time, the rationale for the 60 per cent target fixed in the Treaty was the fact that in the long term the ratio between a 3 per cent deficit and 5 per cent nominal growth would converge to a debt-to-GDP ratio of 60 per cent. The present conditions of secular stagnation, low inflation and low interest rates destroy the economic rationale for that reference value.

The definition of a long-term target for the debt-to-GDP ratio is beset with difficulties. There is no theoretical basis for any particular level. Regarding a rule for the deficit, the proper concept should be the cyclically adjusted primary balance, which is very difficult to calculate with precision and is subject to significant revisions as the measure of the output gap is also revised. It is therefore subject to bitter discussions with member countries on approval and compliance. On the other hand, a good quantitative fiscal rule should be open to change with some contingencies, namely when monetary policy is constrained by the effective lower bound of interest rates. ${ }^{4}$

All these problems lead some economists to despair of finding well-designed quantitative fiscal rules capable of accommodating different objectives and contingencies. Eichengreen/ Wyplocz (2016) go as far as proposing a renationalisation of fiscal policy, as fiscal spillovers among countries are small. ${ }^{5}$ That change would give more responsibility to member states in facing markets because it would be accompanied by a credible no-bailout rule and the increased possibility of debt restructuring.

In the same vein, Blanchard et al. (2019) recently presented a preliminary version of a proposal that would abolish the existing quantitative goals. They would be substituted by guiding principles to be enforced by the EU Commission in a more discretionary way, with the possibility of putting cases of non-compliance to the European Court of Justice. These are intriguing proposals that deserve some consideration given all the problems with the implementation of the Pact over the years. ${ }^{6}$

However, I am not convinced that those two approaches have a realistic chance of being adopted. A possible alternative is a two-pronged approach to revise the European fiscal rule, thinking mostly from the perspective of the euro area's most pressing requirements. On the one hand, the SGP should be revised along the lines of an expenditure rule without a formulaic annual progression towards the long-term target of 60 per cent, keeping the 3 per cent Treaty limit for the nominal deficit but abandoning targets for the structural balance. This new rule could be approved without a Treaty change. At the same time a European Stabilisation Fund (ESF) would be created to deal with really significant asymmetric or symmetric shocks that cannot be easily accommodated by an expenditure fiscal rule.

A few more details about the expenditure rule:

- The expenditures considered would be net of interest payments, unemployment support and increases in revenue due to discretionary changes in taxation.

3. Treaty on Stability, Coordination and Governance in the Economic and Monetary Union (TSCG).

4. See a theoretical background for that possible discussion in Portes/Wren-Lewis (2015).

5. This is confirmed in the recent ECB working paper by Attinasi et al. (2017).

6. For a thorough assessment of the way the Pact has worked, see European Fiscal Board (2019a). 
- The annual target for expenditure growth would depend on a medium-term projection of nominal potential growth and on a judgement about the convergence to the longterm debt ratio target.

- The judgement involved in that component would take into consideration a broader debt sustainability analysis and the conjunctural situation of the economy.

- National Fiscal Councils would prepare the projections for potential growth over the medium term.

This last point is an important difference from a similar proposal made in a Note of the French Conseil D'Analise Économique (Darvas et al. 2018; see also Darvas et al. 2019) that would give the power to the Fiscal Council to decide on the annual target for the expenditure ceiling. Such delegitimisation of national governments and parliaments in fiscal matters lacks democratic justification and could only foster nationalistic populist trends. In my opinion, the national budgets should continue to be subject to the European Semester procedures already in place. Another version of an expenditure rule was proposed by the European Fiscal Board (2019b), but suggests adopting an even stricter annual reduction of the debt ratio, which would be neither acceptable nor desirable.

An expenditure rule is much less pro-cyclical than the present regime but cannot deal efficiently with significant temporary shocks and does not offer a solution if some member states do not want to use the fiscal space they have. For this purpose it is necessary to create a stabilisation fund in the form of a 'rainy-day' fund with borrowing capacity that would provide transfers to be used in public spending with high multipliers. The IMF proposes an annual contribution of 0.35 per cent of GDP to build up the fund. Transfers should not permanently benefit the same countries and, to avoid moral hazard, the use of the ESF should be conditional on past compliance by countries with the existent fiscal rules. Triggering the transfers should be automatically dependent on a threshold indicator based on significant changes in the unemployment rate.

These two reforms, a sensible expenditure rule and a stabilisation capacity, are crucial to making monetary union a truly integrated economic space and disposing of an appropriate macroeconomic stabilisation framework. Without this stabilisation function, monetary union will always be subject to disruptive shocks and dangerous fragmentation.

\section{THE NEED FOR A EUROPEAN SAFE ASSET}

I will now turn to the second required reform I wanted to highlight: the creation of a true capital-market union (CMU) and of a European safe asset.

Financial integration provides risk-sharing mechanisms which can reduce the impact of country-specific shocks and contribute to macroeconomic stability at the European level. Internationally diversified portfolios are more resilient to global and local shocks and can mitigate the impact of such adverse scenarios. Asdrubali et al. (1996), who introduced the methodology being used to estimate this risk-sharing contribution of capital-market integration, has been cogently criticised by Sebastian Dullien (2017) for exaggerating the size of those effects. ${ }^{7}$

7. The main reasons for that exaggeration are: (i) it ignores the possibility of direct spending by the federal government in a single-state stabilising state GDP; (ii) it strips out the effects of transfers and grants in national recessions; (iii) it counts the smoothing of distributed profits by domestic firms as 'smoothing by capital markets'; and (iv) it counts a normal variation of households' savings to smooth consumption as 'smoothing by credit markets'. 
It can nevertheless play a significant role in improving the functioning of the Economic and Monetary Union (EMU).

As I already mentioned, the CMU cannot fully materialise without the existence of a European safe asset that unifies and expands a deep fixed income pan-European market. There are, however, many other reasons justifying the urgent need for such an instrument. As I enumerated elsewhere (Constâncio 2019), a European safe asset is:

1. crucial to solving the question of the concentration of banks' portfolios on domestic sovereign bonds, and important for the stability and robustness of the European banking system;

2. crucial to reduce the scarcity of secure assets, which reinforces the trend to lower yields and increases the temptation for the private sector to create pseudo-safe assets as happened before the crisis, potentially endangering financial stability;

3. crucial for a fully integrated European bond market, which is essential to fostering the international role of the euro; and

4. crucial for monetary policy to benefit from a more representative European yield curve and more appropriate assets to purchase in open-market operations that will be necessary even in normal times in the future.

Let me end with some brief comments on the types of European safe assets that seem more viable, meaning the ones that exclude significant degrees of mutualisation, can attain significant volumes and are issued with a broad spectrum of maturities. These necessary features lead me to exclude several proposals for some form of European safe asset: those linked to a Euro area budget or sovereign wealth fund, as well as the suggestion of issuing Eurobills, initially proposed with mutualisation and linked to expenditures in European projects (see the initial proposal by Philippon/Helwig 2011; see also Bishop 2013 and EU Commission 2014). I sense there is a temptation to go for this solution as a first step, but issuing only a short-term paper would not serve the panoply of objectives that I have mentioned as important. Other proposals include the Purple Bonds (see Bini-Smaghi/Marcussen 2018) and the somewhat obscure idea of using the banks' reserves at the ECB as a basis for a safe asset. The Purple Bonds proposed by Bini-Smaghi/Marcussen (2018) are basically a scheme to transition over 20 years the Blue/Red bonds of the 2011 proposal by Jacques Delpa and Jacob Weizsäcker (2010). The concept implies a degree of mutualisation, even during the transition, which makes it unviable.

We are left with two basic proposals. The first follows the series of papers by Brunnermeier et al. (2017) and was crystallised in the report published by the ESRB (2018), proposing SBBS, a tranched synthetic bond backed by national sovereign bonds. The senior tranche would have very low risk levels, presumably below German debt, as a result of the diversification gains based on historical correlations and of the protection granted by lower-grade tranches. Market practitioners and rating agencies have been sceptical about the instrument, implying that major financial institutions would not issue or buy such a synthetic product. National debt-managing offices (DMOs) have fiercely opposed the scheme, particularly because it was supposed to be launched by private firms without coordination with planned official issues. Finally, in December 2019, the the Economic and Financial Affairs Council (ECOFIN) put aside further consideration of this project. The main substantive concern is a perceived insufficient diversification to ensure that the senior tranche can indeed be as safe as claimed, because correlations between several countries' debt could increase in a stressful situation. Also, it may be difficult to sell the junior tranche at coupons that do not fatally compromise the overall economics of the synthetic security issuance. Indeed, if the junior tranche had to be placed at a relatively high coupon, then the senior tranche would need to offer a lower coupon than Bunds, the strongest bond, in order for the interest collected 
from the pool of national sovereign bonds to be higher than the interest paid for the synthetic product as a whole. Placing the senior tranche at a lower coupon than Bunds is an unrealistic possibility which would render the overall economics of the SBBS unviable. These obstacles could be overcome if there were some form of public support, for instance a small first loss in the junior tranche covered by a public guarantee, jointly provided by member states. At present this seems quite unlikely to be forthcoming and therefore I think this proposal should be abandoned.

The second proposal is the Leandro/Zettelmeyer (2018a) version of the so-called Ebonds proposed in 2010 in the Monti Report to the Commission (Monti 2010). In the new proposal, a European public entity issues securities destined to fund loans to member countries to cover their budget financing needs and those loans would have legal seniority over any other national sovereign debt. Seniority, instead of diversification and tranching, would make these securities as safe as the safest present sovereign bond, depending on the size of the subordinated part related to probabilities of default and loss-given-default rates applicable to each country. The achievable amounts could be considerable, attaining up to 25-30 per cent of euro area GDP, a little more than $€ 3$ trillion. ${ }^{8}$ Adding the remaining triple-A bonds issued by some member countries and the debt issued by the EU Commission and the European Stability Mechanism (ESM), we could achieve a market well over $€ 4$ trillion that would be enough to solve the sovereign-banks feedback loop and the creation of a true capital-market union. To allay concerns of National Treasuries they should all sit on the Board deciding the amounts and timing of issuance of the safe asset. Complementary regulations would ensure that the banks must use the new asset to substitute for their excessive holdings of domestic sovereign debt. The absence of mutualisation should make the scheme agreeable to northern countries. Subordination of the remaining national debts could result in an increased cost of its issuance, which could be a concern for more indebted countries. However, reasonable simulations indicate that this possible cost would be offset by the lower costs of issued safe E-bonds with their coupons being applied to the loans to member countries.

\section{CONCLUSION}

Reducing the risks still haunting the euro area, making it more robust, is an urgent task to allow the full benefits of having taken the unprecedented step of sharing monetary sovereignty.

Any hopes of enhanced sovereignty for Europe in a more fragmented and dangerous geopolitical environment would be dashed without a dependable, robust monetary union.

To achieve that, the present shortcomings around macroeconomic management and the financial stability framework have to be corrected. The role of fiscal policy in macroeconomic stabilisation, beyond the automatic stabilisers, must be fully recognised in a complete revamp of the SGP.

The creation of a European safe asset, to promote a capital-market union, the internationalisation of the euro and the stability of the banking sector, together with an appropriate macroeconomic management function, are the important and urgent reforms towards a more robust and efficient European Economic and Monetary Union.

8. The calculations regarding the Leandro/Zettelmeier (2018b) proposal have been updated with more recent market information in Giudice et al. (2019). 


\section{REFERENCES}

Asdrubali, P., Sorensen, B.E., Yosha, O. (1996): Channels of interstate risk sharing: United States 1963-1990, in: Quarterly Journal of Economics, 111(4), 1081-1110.

Attinasi, M.-G., Lalik, M., Vetlov, I. (2017): Fiscal spillovers in the euro area, a model based analysis, ECB Working Paper No 2040, March.

Bartsch, E., Boivin, J., Fisher, S., Hildebrand, P. (2019): Dealing with the next downturn: from unconventional monetary policy to unprecedented policy coordination, Report, Blackrock Investment Institute, August. (Also published as a SUERF Policy Note, Issue 105, October, URL: https://www.suerf.org/docx/f_77ae1a5da3b68dc65a9d1648242a29a7_8209_suerf.pdf.)

Bernanke, B. (2003): Some thoughts on monetary policy in Japan, Speech, Tokyo, May.

Bini-Smaghi, L., Marcussen, M. (2018): Delivering a safe asset for the euro area: a proposal for a Purple bond transition, URL: https://voxeu.org/article/delivering-safe-asset-euro-area.

Bishop, G. (2013): Bolstering the still-fragile euro: a plan for a temporary Eurobill fund, URL: http://www.grahambishop.com/DocumentStore/08e23646-5275-490b-9442-f1a650db2119. pdf.

Blanchard, O. (2019): Public debt and low interest rates, in: American Economy Review, 109(4), $1197-1229$.

Blanchard, O., Leandro, A., Zettelmeyer, J. (2019): Revisiting the EU fiscal rules in an era of low interest rates, Slide Presentation at the Law and Macro Conference, Georgetown Law.

Brunnermeier, M.K., Langfield, S., Pagano, M., Reis, R., Van Nieuwerburgh, S., Vayanos, D. (2017): ESBies: safety in the tranches, in: Economic Policy, 32(90), 175-219.

Calmfors, L., Wren-Lewis, S. (2011): What should fiscal councils do?, in: Economic Policy, 26(5), 651-695.

Constâncio, V. (2019): European financial architecture and the European safe asset, Conference on European Financial Infrastructure in the Face of New Challenges, Florence, 25 April, URL: https://macroviews.net/wp/.

Darvas, Z., Martin, P., Ragot, X. (2018): European fiscal rules require a major overhaul, Conseil D’Analyse Économique, Note No 47, URL: http://www.cae-eco.fr/IMG/pdf/cae-note047v3. pdf.

Darvas, Z., Martin, P., Ragot, X. (2019): The economic case for an expenditure rule in Europe, in: Pisani-Ferry, J., Zettelmeyer, J. (eds), Risk Sharing Plus Market Discipline: A New Paradigm for Euro Area Reform? A Debate, London: CEPR Press, 123-129.

Delpa, J., Weizsäcker, J. (2010): The Blue bonds proposal, URL: http://bruegel.org/wp-content/ uploads/imported/publications/1005-PB-Blue_Bonds.pdf.

Dullien, S. (2017): Risk sharing by financial markets in Federal systems: what do we really measure? FMM, Working Paper No 2, April.

Eichengreen, B., Wyplocz, C. (2016): Minimal conditions for the survival of the euro, in: Baldwin, R., Giavazzi, F. (eds), How to Fix Europe's Monetary Union: Views of Leading Economists, VoxEU ebook, London: CEPR Press, 33-45.

ESRB (2018): Sovereign bond-backed securities: a feasibility study, URL: https://www.esrb.europa. eu/pub/task_force_safe_assets/shared/pdf/esrb.report290118_sbbs_volume_I_mainfindings.en. pdf.

EU Commission (2014): Final report of the EU Commission Expert Group on redemption fund and Eurobills, URL: http://ec.europa.eu/economy_finance/articles/governance/pdf/ 20140331_conclusion_en.pdf.

European Fiscal Board (2019a): Assessment of EU fiscal rules with a focus on the six and two-pack legislation, August, URL: https://ec.europa.eu/info/sites/info/files/2019-09-10-assessment-of-eufiscal-rules_en.pdf.

European Fiscal Board (2019b): Reforming the EU fiscal framework: a proposal by the European Fiscal Board, in: Pisani-Ferry, J., Zettelmeyer, J. (eds), Risk Sharing Plus Market Discipline: A New Paradigm for Euro Area Reform? A Debate, London: CEPR Press, 130-137.

Fatás, A. (2018): Fiscal policy, potential output and the shifting goalposts, CEPR DP 13149.

Fatás, A., Summers, L.H. (2015): The permanent effects of fiscal consolidations, CEPR DP 10902. 
Giudice, G., de Manuel Aramend, M., Kontolemis, Z., Monteiro, D.P. (2019): A European safe asset to complement national government bonds, MPRA Paper No 95748, URL: https:// mpra.ub.uni-muenchen.de/95748/.

Gordon, R.J. (2016), The Rise and Fall of American Growth: The U.S. Standard of Living Since the Civil War, Princeton, NJ: Princeton University Press.

In't Veld, J. (2013): Fiscal consolidations and spillovers in the Euro area periphery and core, EU Commission Economic Papers No 506.

Leandro, A., Zettelmaeyer, J. (2018a): Safety without tranches: creating a 'real' safe asset for the euro area, CEPR Policy Insight No 93, June.

Leandro, A., Zettelmaeyer, J. (2018b): The search for a Euro Area safe asset, CEPR DP 12793, March.

Monti, M. (2010): A new strategy for the single market, Report to the President of the European Commission.

Philippon, T., Hellwig, C. (2011): Eurobills, not Eurobonds, URL: https://voxeu.org/article/ eurobills-not-euro-bonds.

Portes, J., Wren-Lewis, S. (2015): Issues in the design of fiscal policy rules, in: The Manchester School, 83(S3), 56-86.

Rannenberg, A., Schoder, C., Strasky, J. (2015): The macroeconomic effects of the euro area's fiscal consolidation 2011-2013: a simulation-based approach, Research Technical Paper 03/RT/2015, Central Bank of Ireland.

Summers, L. (2016): The age of secular stagnation: what it is and what to do about it, in: Foreign Affairs, March/April, 2-9.

Thiele, A. (2015): The German way of curbing public debt: the constitutional debt brake and the Fiscal Compact, in: European Constitutional Law Review, 11, 30-54. 